\title{
Coupled Electro-Magneto-Mechanical-Acoustic Analysis Method Developed by Using 2D Finite Element Method for Flat Panel Speaker Driven by Magnetostrictive-Material-Based Actuator
}

\author{
Byungjin Yoo Student Member (Osaka University) \\ Katsuhiro Hirata Senior Member (Osaka University) \\ Atsurou Oonishi Student Member (Osaka University)
}

Keywords: FEM, coupled analysis, acoustic analysis, magnetostriction, flat panel speaker

\section{Introduction}

Giant magnetostrictive materials (GMM) have attracted considerable attention because of their characteristics such as high magnetostriction, strong force and high response speed. Recently, a flat panel speaker system driven by this smart-material-based actuator has been developed. Whereas other standard speaker systems with enclosure create acoustic field, which only spread forward, one of the obvious advantages of speaker system like this is creation of 360-degree acoustic field by vibrating a rigid panel with a GMM actuator. We have presented the magnetic-structural numerical analysis method taking into account nonlinearity of GMM using the finite element method (FEM).

In this paper, a coupled electromagnetic-structural-acoustic analysis method is presented; this method was developed by using FEM. This analysis method is used to predict the performance of a flat panel speaker in the audio-frequency range. The validity of the analysis method is verified by comparing with the measurement results of a prototype speaker.

\section{Magnetostrictive Flat Panel Speaker}

The structure of GMM actuator is shown in Fig. 1. The primary components of the actuator are two GMM rods, permanent magnets and a wound coil with 700 turns for driving. An aluminum panel is used as a flat panel. Since the GMM actuator is axially symmetric, the analysis is conducted using a $2 \mathrm{D}$ axially symmetric model. Figure 2 shows the analyzed model, including the air domain considered for calculating the sound pressure level (SPL). The air domain extends to $1 \mathrm{~m}$ around the panel and a perfectly matched layer (PML) is constructed around the air domain for avoiding reflection of sound pressure.

\section{Characteristics of sound pressure level}

The SPL measurement of the speaker driven by a GMM actuator

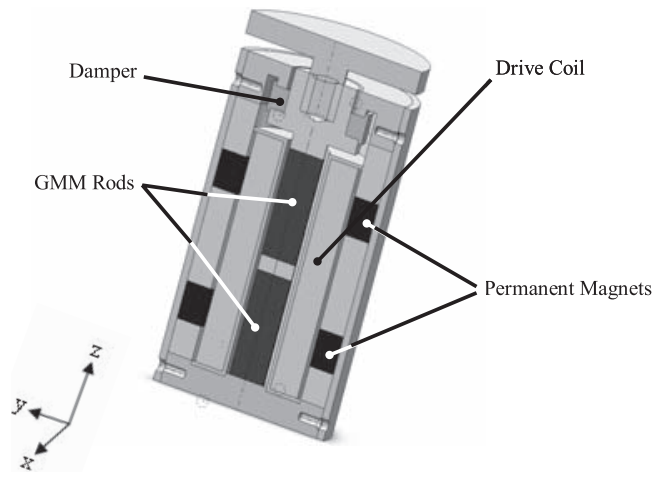

Fig. 1. Structure of GMM actuator is conducted in an anechoic room. A microphone for picking up the sounds is installed $1 \mathrm{~m}$ from the aluminum panel. The frequency range to drive the actuator is verified from $400 \mathrm{~Hz}$ to $20 \mathrm{kHz}$ as well as analyzed conditions. Figure 3 shows the SPL comparison between analyzed and measured results. As can be seen, the analyzed results agree well with the measured ones at all frequencies. Thus, the validity of the analysis method is confirmed.

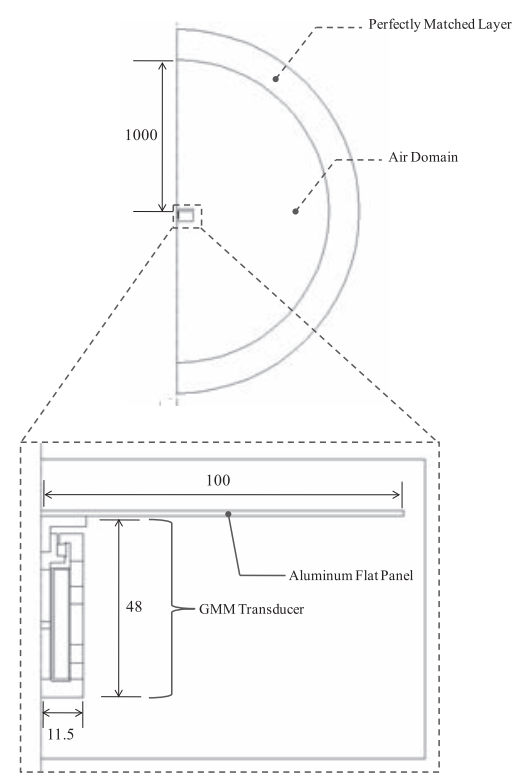

Fig. 2. Analysis model for Magnetostrictive Flat Panel Speaker

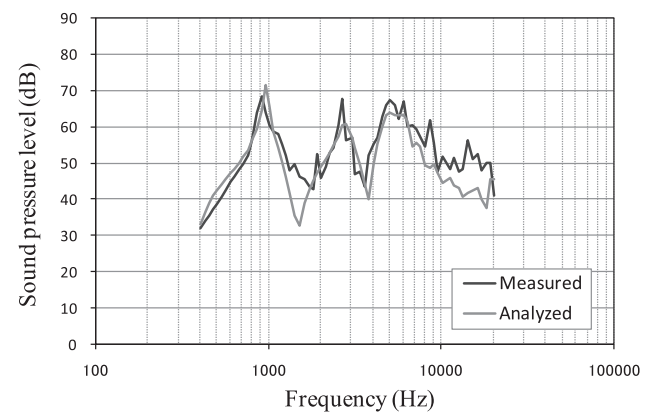

Fig. 3. Comparison between analyzed and measured results of sound pressure level 


\title{
超磁歪アクチュエータを用いた平面スピーカーの 磁場・構造・音場の連成解析手法に関する研究
}

\author{
学生員 軨 炳振 ${ }^{*}$ 上級会員 平田 勝弘* \\ 学生員 大西 敦郎*
}

\section{Coupled Electro-Magneto-Mechanical-Acoustic Analysis Method Developed by Using 2D Finite Element Method for Flat Panel Speaker Driven by Magnetostrictive-Material-Based Actuator}

\author{
Byungjin Yoo*, Student Member, Katsuhiro Hirata*, Senior Member, Atsurou Oonishi*, Student Member
}

In this study, a coupled analysis method for flat panel speakers driven by giant magnetostrictive material (GMM) based actuator was developed. The sound field produced by a flat panel speaker that is driven by a GMM actuator depends on the vibration of the flat panel, this vibration is a result of magnetostriction property of the GMM. In this case, to predict the sound pressure level (SPL) in the audio-frequency range, it is necessary to take into account not only the magnetostriction property of the GMM but also the effect of eddy current and the vibration characteristics of the actuator and the flat panel. In this paper, a coupled electromagnetic-structural-acoustic analysis method is presented; this method was developed by using the finite element method (FEM). This analysis method is used to predict the performance of a flat panel speaker in the audio-frequency range. The validity of the analysis method is verified by comparing with the measurement results of a prototype speaker.

キーワード : 有限要素法, 連成解析, 音響解析, 磁歪, 平面スピーカー

Keywords: FEM, coupled analysis, acoustic analysis, magnetostriction, flat panel speaker

\section{1. まえがき}

超磁歪材料は大きい形状変化率を持ち, エネルギー密度が 高く, 耐久性に優れ，また環境にも優しいという特徵を持っ た非常に有用な機能性材料であるためアクチュエータやセ ンサーなどの様々なデバイスに応用が検討されている(1)。 著者らはこの超磁歪材料を用いたデバイスの設計の効率向 上のため，材料特性の非線形性が高い超磁歪材料の非線形 性を考慮した様々な解析手法を提案してきた ${ }^{(2) ~(5) 。 ~}$

近年，超磁歪素子を用いたアクチュエータの主な実用化 例としては平面スピーカーに搭載されているエキサイター がある ()。そのエキサイターは主に超磁歪材料と, その周 りに巻かれたコイルとバイアス用の永久磁石からなり, 磁 束が漏れないように磁気回路を形成した構成である。コイ ルに電流を励磁し, 起磁力を発生させることにより超磁歪 素子のジュール効果を引き起こさせ, 発生した超磁歪素子

\footnotetext{
* 大阪大学 大学院工学研究科 知能 - 機能創成工学専攻

于 565-0871 吹田市山田丘 2-1

Dept. of Adaptive Machine Systems, Graduate School of Engineering, Osaka University

2-1, Yamadaoka, Suita 565-0871
}

の伸縮を直接変位として取り出してパネルやテーブルなど を振動させることで音が発生するような機能を果たしてい る。エンクロージャーで囲まれている通常の指向性を持つ スピーカーがスピーカーの前面にほとんどの音場を形成す ることに対し，このような平面スピーカーの利点はエンク ロージャーがなく，パネルのような振動板の振動を直接用 いることでスピーカーを中心に全方位で音場を作ることが でき, 大公演場や展示場, 薄型ディスプレーなどへ応用が 期待されている。しかし, 音圧レベルが低く, スピーカー として最も重要な可聴領域での音響特性が良くないといっ た問題を抱えているのが現状である。超磁歪アクチュエー 夕を用いた平面スピーカーから発生する音は超磁歪素子の ジュール効果によるパネルの振動に大きく依存する。その ためこおような平面スピーカーの設計段階において可聴領 域でスピーカーの音圧レベルや音響特性などを予測するた めには磁界・構造・音場の非常に複雑で大規模な物理的連 成系（マルティフィジクス）を同時に考慮しなければなら ないので, 計算機による解析シミュレーションへの期待が 高まっている。

一方, 超磁歪素子を用いたアクチュエータから発生する 音の解析シミュレーションに関しては超磁歪ソナーの水中 
音響特性解析に関する報告がなされている(7)。しかし，こ の解析手法では永久磁石によるバイアス磁界を有しないモ デルを用いて磁界解析と構造解析においてそれぞれ異なる 解析モデルを作成し, 磁界と構造解析を分離した解析手法 であるので, 通常バイアス磁石を搭載する超磁歪アクチュ エータの特性を説明するには限界がある解析方法であると 考えられる。また, 解析手法の実験検証も行っていない。

そこで本稿では, 超磁歪アクチュエータを用いた平面ス ピーカーの音場特性を予測するため有限要素法による磁界・ 構造・音場の連成解析手法について述べる。また, 超磁歪 アクチュエータを用いた平面スピーカーを試作し，そのス ピーカーを解析モデルとして超磁歪素子のジュール効果に よるパネルの振動から生じる音圧レベル解析を行う。更に, 試作機による実験結果と解析結果との比較検証を行うこと で本解析手法の妥当性を明らかにする。

\section{2. 有限要素法による解析手法}

$\langle\mathbf{2} \cdot \mathbf{1}\rangle$ 磁界解析 周波数領域における磁界解析の基 礎方程式は, 磁気ベクトルポテンシャル $\dot{A}$ を用いて次式の ように表わされる。

$$
\left\{\begin{array}{l}
\operatorname{rot}(\dot{v} \operatorname{rot} \dot{\boldsymbol{A}})=\dot{\boldsymbol{J}}_{0}+\dot{\boldsymbol{J}}_{e}=\dot{\boldsymbol{J}}_{0}-\sigma(j \omega \dot{\boldsymbol{A}}+\operatorname{grad} \dot{\phi}) \\
\operatorname{div} \dot{\boldsymbol{J}}_{e}=0
\end{array}\right.
$$

ここで $\dot{v}$ は磁気抵抗率， $\boldsymbol{J}_{0}$ は強制電流密度， $\boldsymbol{J}_{e}$ は渦電流 密度， $\sigma$ は導電率， $\omega$ は角速度および $\dot{\phi}$ は電気スカラーポ テンシャルであり，ドッド (.) は複素数を表わす。

また, 本解析では回路方程式との連成解析を行っている。

$$
\dot{V}_{0}=R \dot{I}_{0}+j \omega \dot{\psi}
$$

ここで $\dot{V}_{0}$ は印加電圧， $R$ は抵抗， $\dot{I}_{0}$ は励磁電流， $\dot{\psi}$ は励磁 コイルの鎖交磁束を表す。

$\langle\mathbf{2} \cdot 2\rangle$ 構造解析 超磁歪材料のジュール効果による 素子の振動をモデリングするためには超磁歪材料が磁界と 構造の強連成関係であるため, 通常の運動方程式に素子に 与えられた磁界による応力成分を考慮しなければならない。 これらの関係を一つの式にまとめると以下のような式で表 すことができる。

$$
\nabla \cdot\left(\boldsymbol{T}_{m e c h}+\boldsymbol{T}_{M}\right)+\boldsymbol{b}_{m e c h}=\rho \frac{d^{2} \boldsymbol{u}}{d t^{2}}
$$

ここで $\boldsymbol{T}_{\text {mech }}$ は素子の伸縮変形により生じる応力テンソル, $\boldsymbol{T}_{M}$ はマクスウェルの応力テンソル $\boldsymbol{b}_{\text {mech }}$ は機械的物体力, $\rho$ は質量密度，また $\boldsymbol{u}$ は変位べクトルを表している。尚，マ クスウェルの応力テンソルは以下のように表わされる(8)。

$$
\boldsymbol{T}_{M}=\boldsymbol{H} \otimes \boldsymbol{B}-\frac{\mu_{0}}{2}(\boldsymbol{H} \cdot \boldsymbol{H}) \boldsymbol{I}
$$

ここで $\boldsymbol{H}$ は磁界強度, $\boldsymbol{B}$ は磁束密度, 演算子 $\otimes$ はテンソ ル積, $\mu_{0}$ は真空中の透磁率マトリックス, I は単位行列を 表している。
〈2·3 磁歪材料の連成方程式磁歪材料の性質を表 す式として, 機械的な応力とひずみ, 磁界と磁束密度を連 成した方程式が二つ存在する。これらの関係は本来ならば 非線形であるが, 微小变位と仮定することで線形に近似で きる。線形に近似された連成式は次式のように与えられる。

$$
\begin{aligned}
& \boldsymbol{S}=\boldsymbol{c}^{H} \boldsymbol{T}_{\text {mech }}+\left(\boldsymbol{d}^{T}\right)^{t} \boldsymbol{H} . \\
& \boldsymbol{B}=\boldsymbol{d}^{H} \boldsymbol{T}_{\text {mech }}+\mu^{T} \boldsymbol{H}
\end{aligned}
$$

ここで, $\boldsymbol{c}^{H}$ は弾性コンプライアンス, $\boldsymbol{d}$ は磁歪定数, $\boldsymbol{\mu}$ は 透磁率, 上付き文字 $t$ は転置行列を示す。尚, 以後の上付 き文字 $T, H, S$ は一定応力下, 一定磁界下, 一定ひずみ 下を表している。(5) 式と (6) 式は磁歪定数 $\boldsymbol{d}$ で連結されて いるので通常 $d$-type と呼ばれる。これらの式は必要に応じ て様々な形に変換することができるが, 本解析手法では解 析を行いやすいように, ひずみと磁束密度によって応力と 磁界の強さが表されるように変換する。そのためにはまず (5) 式を次式のように変換する。

$$
\boldsymbol{T}_{\text {mech }}=\boldsymbol{c}^{H}\left[\boldsymbol{S}-\left(\boldsymbol{d}^{T}\right)^{t} \boldsymbol{H}\right]=\boldsymbol{c}^{H} \boldsymbol{S}-\boldsymbol{g} \boldsymbol{H} .
$$

ここで, $\boldsymbol{g}=\boldsymbol{c}^{H}\left(\boldsymbol{d}^{T}\right)^{t}$ である。そして (7) 式を (6) 式に代入 すると次式が得られる。

$$
\boldsymbol{B}=\boldsymbol{d}^{H} \boldsymbol{c}^{H} \boldsymbol{S}+\left(\boldsymbol{\mu}^{T}-\boldsymbol{d}^{H} \boldsymbol{g}\right) \boldsymbol{H}=\boldsymbol{g}^{\prime} \boldsymbol{S}+\boldsymbol{\mu}^{S} \boldsymbol{H}
$$

ここで, 独立変数の微少増加では $\boldsymbol{d}^{H}=\left(\boldsymbol{d}^{T}\right)^{t}=\boldsymbol{d}$ と仮定で きるので, $\boldsymbol{g}^{\prime}=\boldsymbol{d}^{H} \boldsymbol{c}^{H}=\boldsymbol{d} \boldsymbol{c}^{H}=\left(\boldsymbol{c}^{H} \boldsymbol{d}^{t}\right)^{t}=\boldsymbol{g}^{t}, \boldsymbol{\mu}^{S}=\boldsymbol{\mu}^{T}-\boldsymbol{d g}$ である。同様に，(8) 式を磁界の式に変形すると次式が得ら れる。

$$
H=-\boldsymbol{v}^{s} g^{t} S+\boldsymbol{v}^{s} B=h^{t} S+\boldsymbol{v}^{s} B
$$

ここで, $\boldsymbol{h}^{t}=-\boldsymbol{v}^{s} \boldsymbol{g}^{t}$ である。最後に (9) 式を (7) 式に代入す ると次式が得られる。

$$
\boldsymbol{T}_{\text {mech }}=\left[\boldsymbol{c}^{H}-\boldsymbol{g} \boldsymbol{h}^{t}\right] \boldsymbol{S}-\boldsymbol{g} \boldsymbol{v}^{s} \boldsymbol{B} .
$$

以上のように変換した (9) 式と (10) 式を用いて超磁歪材 料の磁界と構造の連成解析を行う。

$\langle\mathbf{2} \cdot \mathbf{4}\rangle$ 音場解析 通常, 従来から構造物の振動により 発生する音場の挙動を記述する方法は一般的に Lagrangian 手法と Eulerian 手法という二つの方法が知られている ${ }^{(9)}$ 。 本解析では, 解析にかかる時間の短いメリットがある $\mathrm{Eu}-$ lerian 手法を用いた。この手法は本来流体の流れ場である 音場を表す支配方程式を圧力ポテンシャルに関する波動方 程式として記述することができる手法である。

本稿の音場解析に用いた支配方程式は周波数領域下での Helmholtzの波動方程式であり, 以下のように表現するこ とができる。

$$
\nabla \cdot\left(-\frac{1}{\rho_{0}} \nabla \boldsymbol{P}\right)-\frac{\omega^{2} \boldsymbol{P}}{\rho_{0} c^{2}}=0
$$

ここで $\rho_{0}$ は媒質密， $P$ は圧力, $c$ は音速である。 


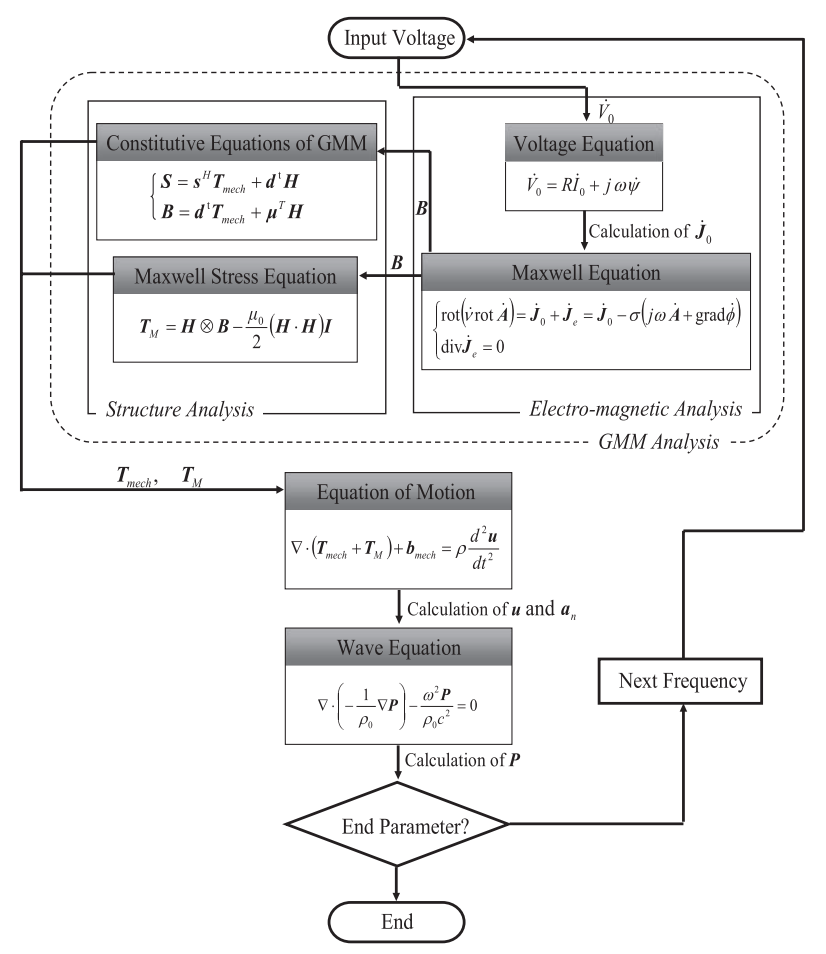

図 1 解析フローチャート

Fig. 1. Flowchart for analysis.

構造物が振動する際，周波数領域での音場解析は媒質に 囲まれている構造物の各面での法線方向の速度や加速度を 計算することで音圧を算出することが出来る。本稿の解析 では, 超磁歪アクチュエータの振動より発生したパネルの 振動による音圧は, 構造解析より求められたパネル各要素で の法線方向の振動加速度を以下の (12) 式に代入することで 音圧ポテンシャルを求め, 最終的に音圧レベルを計算した。

$$
\boldsymbol{a}_{n}=\bar{n} \cdot\left(-\frac{1}{\rho_{0}} \nabla \boldsymbol{P}\right)
$$

ここで, $\boldsymbol{a}_{n}$ はパネル部の法線加速度， $\bar{n}$ はパネルと媒質と の境界面に対する法線べクトルである。

$\langle\mathbf{2} \cdot \mathbf{5}\rangle$ 磁界・構造・音場の連成解析手法 以下の図 1 に本稿で用いた解析手法のフローチャートを各解析段階で 用いた支配方程式と共に表す。

（1）超磁歪素子における磁界と構造の連成解析を行う。

（2）上記 (1)の結果を用いて, 超磁歪アクチュエータ の振幅を計算する。

（3）上記(2)の結果を用いて，パネル領域の各要素に おける振動の法線方向加速度を算出する。

（4）上記 (3)の結果を用いて，流体領域の音圧を算出 する。

（5）各周波数における計算が終わるまで，この操作を 繰り返す。

\section{3. 解析モデルおよび解析条件}

〈3・1〉解析モデル 図 2 に試作した超磁歪アクチュ エータの断面図を示す。アクチュエータは振動部の $\phi 5 \mathrm{~mm}$,

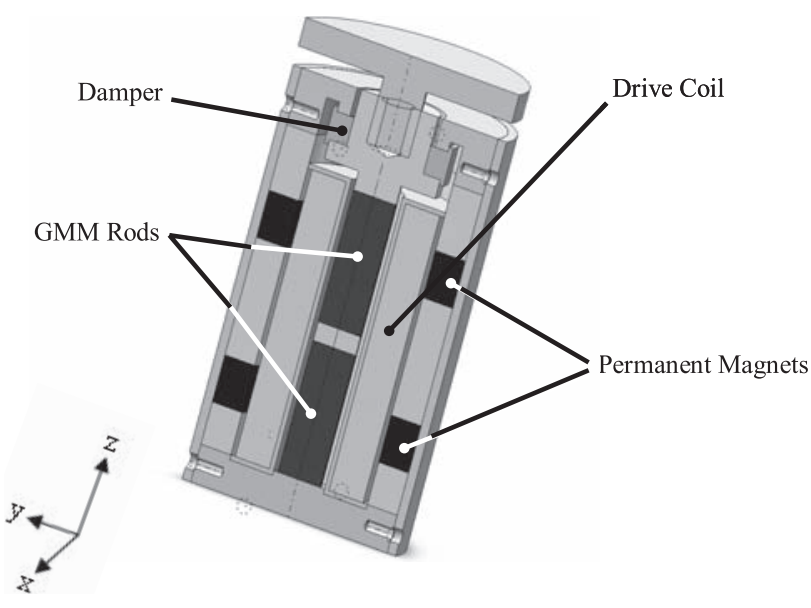

図 2 超磁歪アクチュエータの構造

Fig. 2. Structure of GMM actuator.

高さ $14 \mathrm{~mm}$ の円柱状超磁歪素子 2 本とシャフト, ヘッドお よび固定部の外径 $\phi 23 \mathrm{~mm}$, 内径 $\phi 16 \mathrm{~mm}$, 高さ $5.4 \mathrm{~mm}$ の 円筒形のバイアス磁石 2 個 (フェライト, $(B r=0.4 \mathrm{~T})$ ), 励 磁コイル (700 ターン, 約 4 オーム) およびョーク (SUY : 電磁軟鉄）からなる。バイアス磁石により超磁歪アクチュ エータには約 $18 \mathrm{kA} / \mathrm{m}$ のバイアス磁界が与えられている。

本アクチュエータは軸対称の構造であるため, 解析は二 次元軸対称モデルを作成し行った。解析モデルを図 3 に示 す。解析モデルの中央に超磁歪アクチュエータと円盤形の アルミニウムパネルが配置され，パネルの周囲 1 メートル には媒質である空気層を設定した。また，無響室のように 音の反射をなくし，有限の空間でありながら音響的に無限 の広さをもった空間と等価な状態である自由音場をモデリ ングするため，音圧反射を防ぐような完全吸収条件 (PML) を空気層の外側に $200 \mathrm{~mm}$ の厚さで作成した。また，解析 モデルにおける音圧レベル計算のための境界条件としては, パネルと媒質との境界に対して境界線上の全ての要素接点 で法線方向の加速度が計算できるように設定を行った。

音のような波動現象の解析を行う際には, メッシュの大き さが計算する周波数の波長以下になるように作成する必要 がある。そのため, 可聴領域での最大周波数である $20 \mathrm{kHz}$ で音の波長が約 $17 \mathrm{~mm}$ (常温基準) であることから，空気 領域の最大メッシュ長を $10 \mathrm{~mm}$ とした。また, 超磁歪ア クチュエータの磁気回路部も渦電流を考慮した磁界解析を 行うために, 磁気回路部の各々の材質について超磁歪アク チュエー夕を駆動する最大周波数である $20 \mathrm{kHz}$ での表皮 深さを算出しその表皮深さに対してメッシュが少なくとも 2 層の構成になるように最大要素長を決めた。

$\langle\mathbf{3 \cdot 2 \rangle}$ 磁界の周波数領域解析時のバイアス磁界モデル 化 通常, 有限要素法の j $\omega$ 法による周波数領域での磁 界解析は, 永久磁石のようなバイアス磁界をモデル化する ことが困難である。その理由としては磁界が周波数領域で 正弦波状に変化することを前提として解析を行うためであ る。このことより, 実機では本来ならば超磁歪素子がバイ 


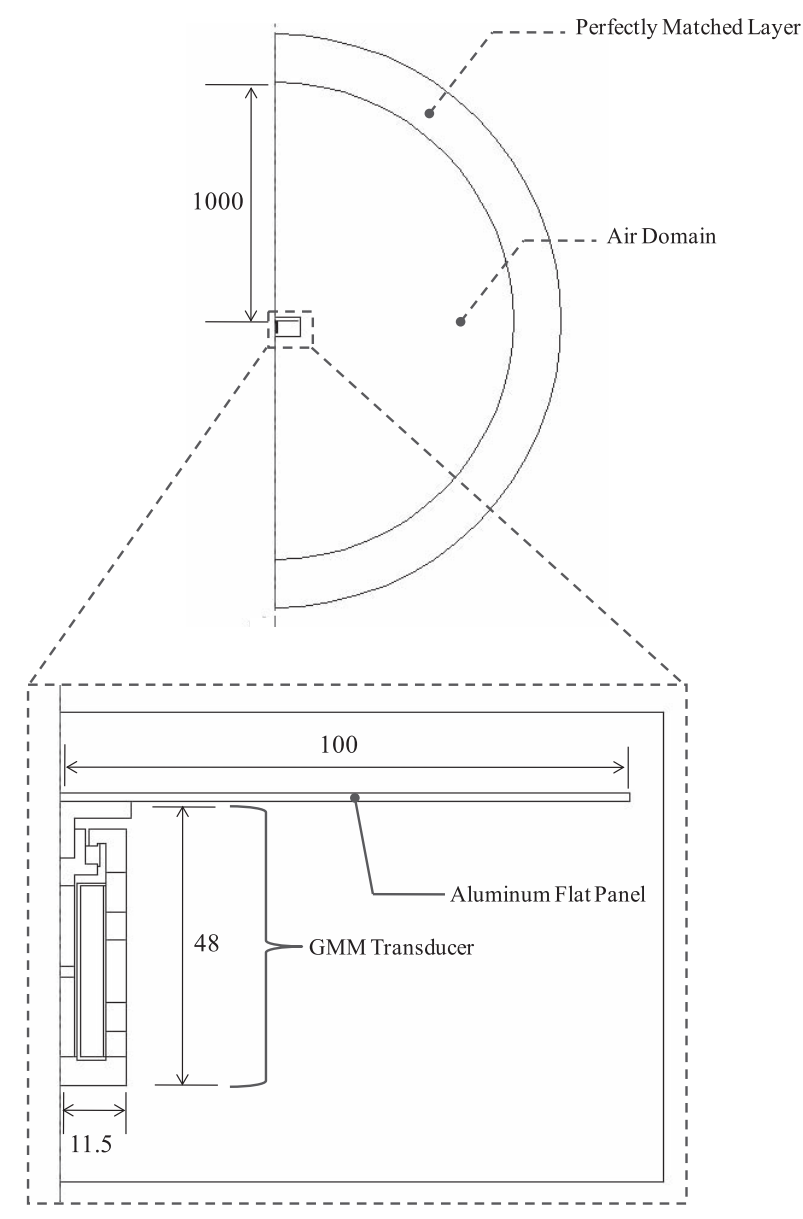

図 3 解析モデル

Fig. 3. Analysis model.

アス磁界により既に伸びている状態でコイルに正弦波電流 を励磁することによる磁界の変化に応じた磁歪量のみがア クチュエータの振幅になるが，有限要素法を用いた周波数 応答解析モデルにおいてバイアス磁石を搭載すると，解析 結果として計算される超磁歪アクチュエータの振幅はバイ アス磁界より生じる磁歪量とコイルに励磁することで生じ る磁歪量が合計された值になる。従って，周波数応答解析 において通常的に超磁歪アクチュエータに搭載されている バイアス磁石をモデル化するためには新たな工夫が必要で ある。

そこで図 4 に示すように周波数応答解析においてもバイ アス磁界のモデル化ができるように超磁歪材料の材料曲線 の修正を行った。各々の材料デー夕曲線を $0 \mathrm{~A} / \mathrm{m}$ にシフト した曲線を用いることで周波数領域の解析上でバイアス磁 石を与えなくてもバイアス磁界付近での超磁歪素子の材料 デー夕を用いることができ，超磁歪素子の磁歪を引き起こ す磁界はコイルに励磁された電流による磁界のみとなる。

$\langle\mathbf{3} \cdot \mathbf{3}\rangle$ 解析条件 本解析パラメータとして, 入力電 圧の変化による音圧レベルの変化を調べるため，アクチュ エータのコイルへの入力電圧を $1 \mathrm{~V} ， 2 \mathrm{~V} ， 3 \mathrm{~V}$ としたま た，駆動周波数を $400 \mathrm{~Hz}$ から $20 \mathrm{kHz}$ の領域において，通常

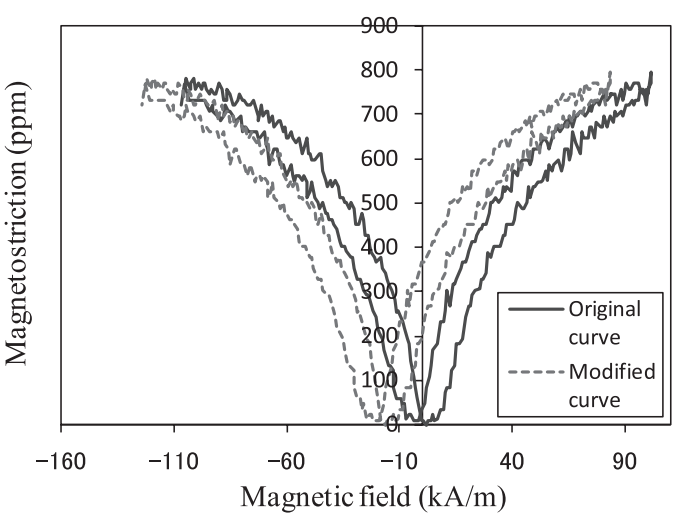

(a) 超磁歪素子の $\boldsymbol{H}$ - $\lambda$ 曲線の修正

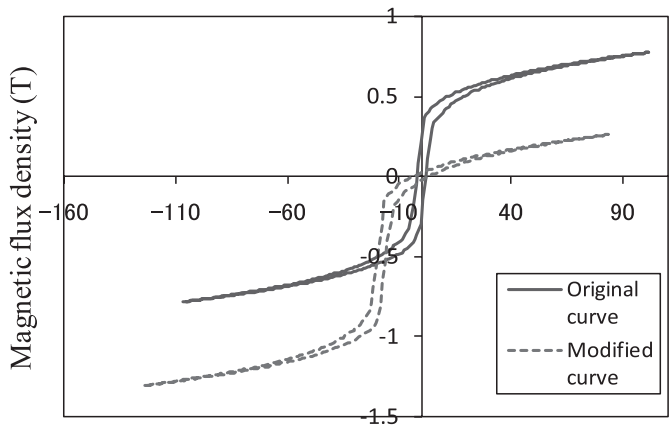

Magnetic field $(\mathrm{kA} / \mathrm{m})$

(b) 超磁歪素子の $\boldsymbol{B}-\boldsymbol{H}$ 曲線の修正

図 4 超磁歪材料曲線の修正

Fig. 4. Modification of GMM material curves.

表 1 解析諸元

Table 1. Discretization data and CPU time.

\begin{tabular}{|c|r|}
\hline Number of elements & 402,943 \\
\hline Number of nodes & 201,893 \\
\hline Number of input frequency parameters & 68 \\
\hline CPU time (hours) & 2.5 \\
\hline
\end{tabular}

Computer specifications: Xeon (3.0 GHz), 16GB memory.

的に実測でスピーカーの音響特性分析を行う時用いる $1 / 12$ オクターブ分析ができるように周波数の刻み幅を分けて, 計算される音圧レベルの周波数特性での分解能を高めた。

また，超磁歪材料は本来ならば磁界の変化によって磁歪 定数と透磁率が大きい非線形性を持つが，小さい磁界の変 化領域では線形として仮定できる。そこで著者らは前回報 告した超磁歪材料の非線形性を考慮した解析手法 ${ }^{(5)}$ を用い, 先行解析として上記に述べたアクチュエータの入力電圧に よる超磁歪素子に与えられる磁界の変化を調べた結果，バ イアス磁界 $(18 \mathrm{kA} / \mathrm{m})$ を中心にアクチュエータの入力電 圧の最大值 $3 \mathrm{~V}$ により, 正負で最大約 $16 \mathrm{kA} / \mathrm{m}$ の磁界の変 化が確認され, しかも磁歪定数と非透磁率の非線形性がほ とんど現れ無かった。その結果を踏まえ，本解析の入力電 圧による磁界变化量は超磁歪素子の材料特性がほぼ線形的 


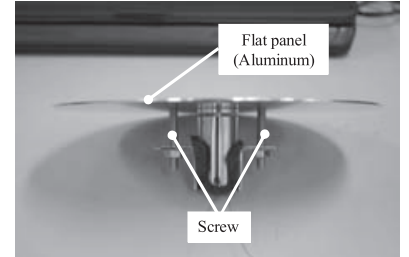

(a)

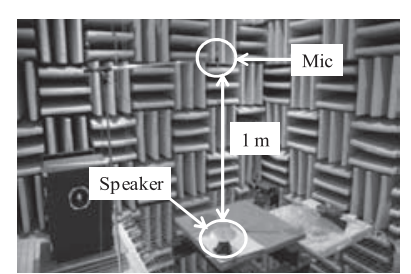

(b)
図 5 (a) 超磁歪平面スピーカー, (b) 音圧レベル 測定環境

Fig. 5. The SPL measurement environment. (a) Prototype GMM speaker, (b) SPL measurement.

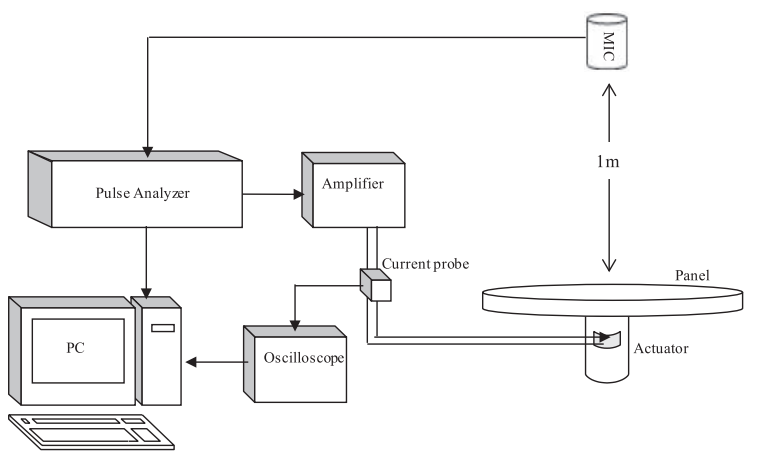

図 6 実験装置

Fig. 6. Experimental setup.

な区間内であることから，超磁歪材料の非線形性を考慮す る必要性がないと判断し，材料の線形デー夕を用いて解析 を行った。さらに，解析諸元については表 1 に示す。

\section{4. 実 測}

図 5 に試作した超磁歪アクチュエータを用いた平面ス ピーカーを示す。スピーカーは主に超磁歪アクチュエータ と $\phi 200 \mathrm{~mm}$, 厚さ $1.5 \mathrm{~mm}$ のアルミニウムの円盤形パネル からなる。超磁歪アクチュエータと振動板の固定方法は同 罒で示すように，ネジより固定されている。また，超磁歪 アクチュエータより駆動する平面スピーカーの音圧レベル 測定は同図に示すように床や天井を含む全ての壁面が吸音 力の大きな材料で囲まれた無響室で行った。

次に，スピーカーの音圧レベルの特性評価実験システム の構成を図 6 に示す。パルスアナライザーにより発生され る電圧をアンプにて増幅し，アクチュエータのコイルに印 加する。その時，コイルに流れる電流は電流プローブを用 いて計測している。一方，発生した音はパネルから $1 \mathrm{~m}$ 離 れたところに設置されたマイクにてピックアップされ，そ の音響信号は再びパルスアナライザーを通り計算機にデー 夕が入力され FFT フィルタリングによる周波数領域でデー 夕整理されて最終的にはパソコンで可視化される。

本実験では入力 $\mathrm{AC}$ 電圧を解析と同様に $1 \mathrm{~V}$ から $3 \mathrm{~V}$ とし 駆動周波数を $400 \mathrm{~Hz}$ から $20 \mathrm{kHz}$ までの領域において $1 / 12$ オクターブ分析ができるように周波数の刻み幅を分けて， 測定される音圧レベルの周波数特性での分解能を高めた。

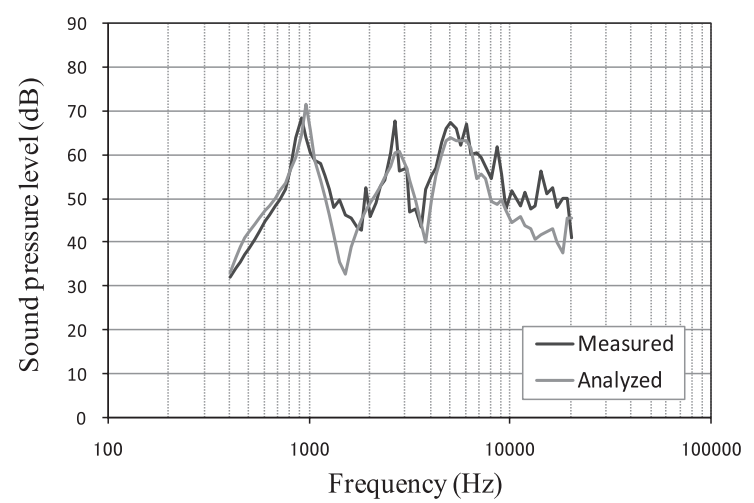

(a)

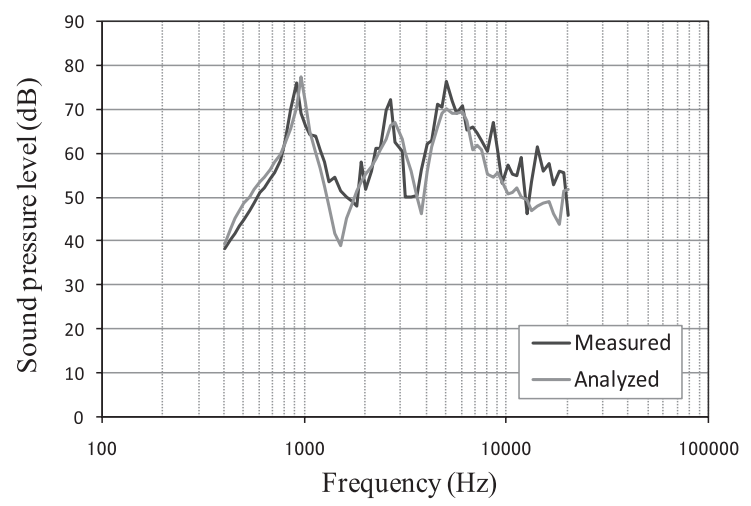

(b)

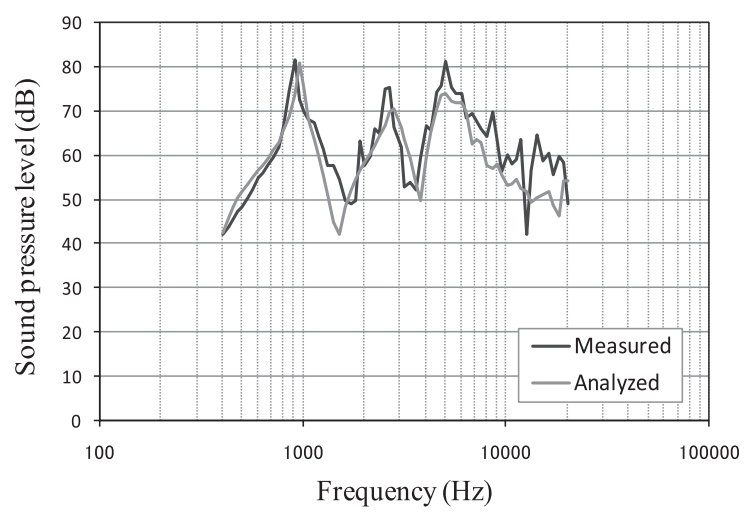

(c)

図 7 測定箇所 I での音圧レベルの解析結果と 実測結果の比較 (a) $1 \mathrm{~V}$ 入力，(b) $2 \mathrm{~V}$ 入力， (c) $3 \mathrm{~V}$ 入力

Fig. 7. Comparison between analyzed and measured results of sound pressure level. (a) input 1 Volt, (b) input 2 Volt, (c) input 3 Volt.

\section{5. 解析結果と実測結果との比較検証}

図 7 に各入力電圧に対する測定した音圧レベルの結果と 解析結果の比較を示す。同結果より，各入力電圧下での解 析結果と実測結果が定性的に, 定量的に良い一致を示して いることがわかる。また同図より，実測結果と解析結果で 音圧レベルのピーク点が 3 ケ所見られた。これらの音圧レ ベルのピークは図 8 で表す本超磁歪スピーカーのモーダル 解析結果より, 各々順次的にパネルの縦方向振動の 1 次モー 


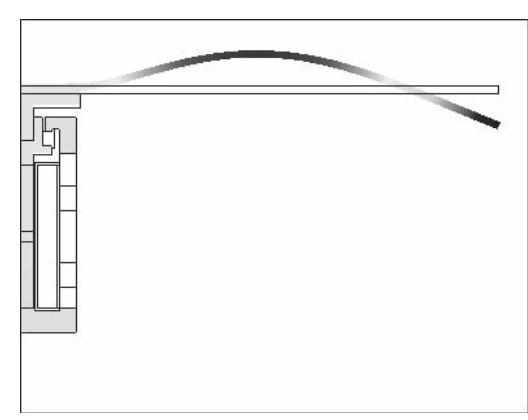

(a)

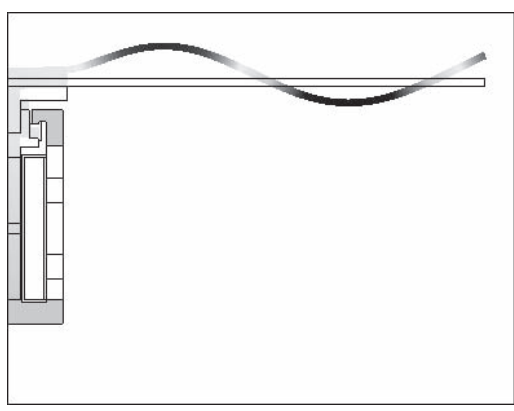

(b)

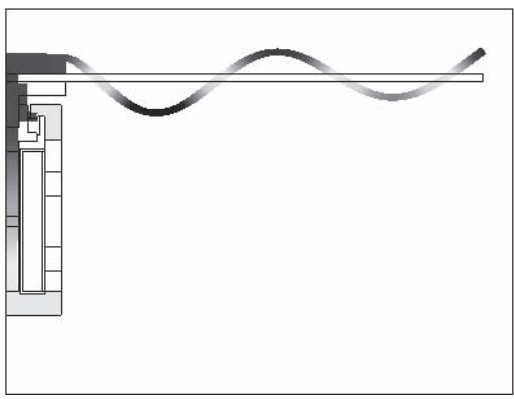

(c)

図 8 超磁歪スピーカーの固有振動 (a) $957 \mathrm{~Hz}$,

(b) $2678 \mathrm{~Hz}$, (c) $5917 \mathrm{~Hz}$

Fig. 8. The eigen frequeuncy of prototype speaker. (a) $957 \mathrm{~Hz}$, (b) $2678 \mathrm{~Hz}$, (c) $5917 \mathrm{~Hz}$.

ド (約 $1 \mathrm{kHz}$ ), 超磁歪アクチュエータの縦方向振動のモー ドとパネルの 2 次モード (約 $2.6 \mathrm{kHz}$ ), 最後にドミナント的 な超磁歪アクチュエータの共進とパネルの 3 次モード（約 $6 \mathrm{kHz})$ より生じたと考えられる。

一方で, 約 $10 \mathrm{kHz}$ から $20 \mathrm{kHz}$ までの高周波領域では解 析結果と実験結果が最大 $15 \mathrm{~dB}$ の誤差が見らた。このよう な高周波領域での解析結果と実測結果との誤差原因は図 9 に示す音圧レベルの分布図から，低周波領域ではパネルを 中心にそこからの距離が遠くなると音圧レベルが低くなる が，約 $10 \mathrm{kHz}$ 以上の高周波領域になると音の指向性が強 く現れ，図 10 に示す $20 \mathrm{kHz}$ での音圧勾配の解析結果を見 ると，パネルの中心から離れた位置での音圧グラジエント は複雑な方向性を持っていることがより確実に確認できる。 これらの解析結果によって確認できるように, 約 $10 \mathrm{kHz}$ 以 上の周波数領域での誤差原因は実測におけるパネルとマイ クとの角度や姿勢偏差による計測誤差に原因があると考え られる。

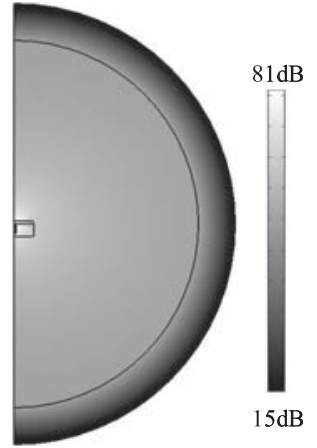

(a) $400 \mathrm{~Hz}$

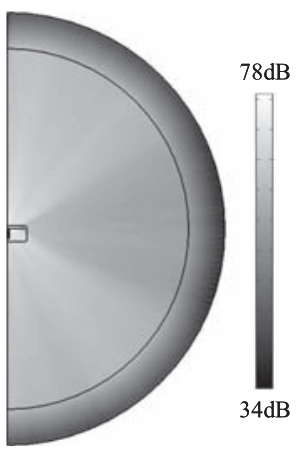

(c) $15 \mathrm{kHz}$

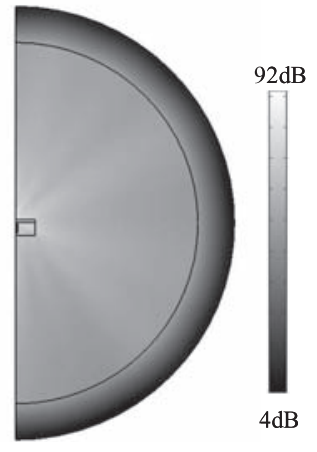

(b) $10 \mathrm{kHz}$

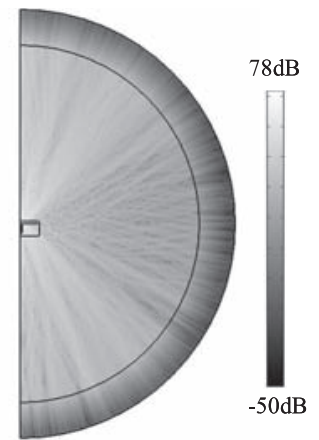

(d) $20 \mathrm{kHz}$
図 $92 \mathrm{~V}$ 入力時の周波数別音圧レベル分布図

Fig. 9. Sound pressure distribution at each frequency with $2 \mathrm{~V}$ input voltage.

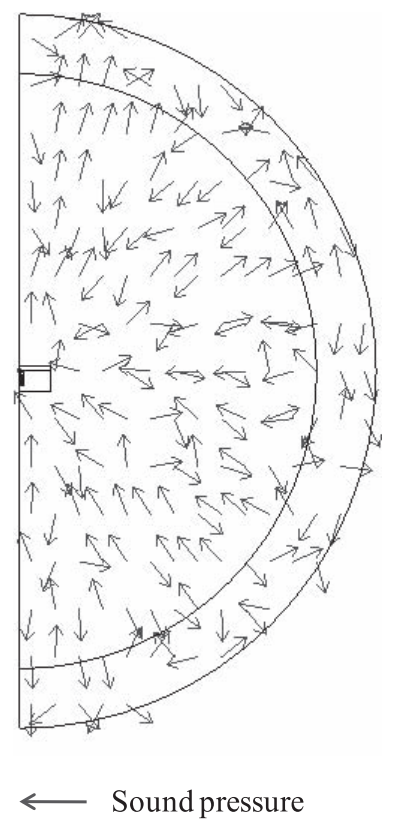

図 $102 \mathrm{~V}$ 入力， $20 \mathrm{kHz}$ の時の音圧勾配

Fig. 10. Sound pressure gradient at $20 \mathrm{kHz}$ with $2 \mathrm{~V}$ input voltage.

\section{6. 本解析手法を用いたパネル材別音響特性の変化} 検討

本稿で提案し実測検証した解析手法を用いて，パネルの 
表 2 各パネルのヤング率と密度

Table 2. Young's modulus and density of each flat panel material.

\begin{tabular}{|c|r|r|}
\hline & $\begin{array}{c}\text { Young's modulus } \\
(\mathrm{GPa})\end{array}$ & $\begin{array}{c}\text { Desity } \\
\left(\mathrm{kg} / \mathrm{m}^{3}\right)\end{array}$ \\
\hline $\mathrm{Al}$ & 70 & 2700 \\
\hline $\mathrm{SiC}$ & 490 & 4090 \\
\hline Acrylic resin & 70 & 1160 \\
\hline
\end{tabular}

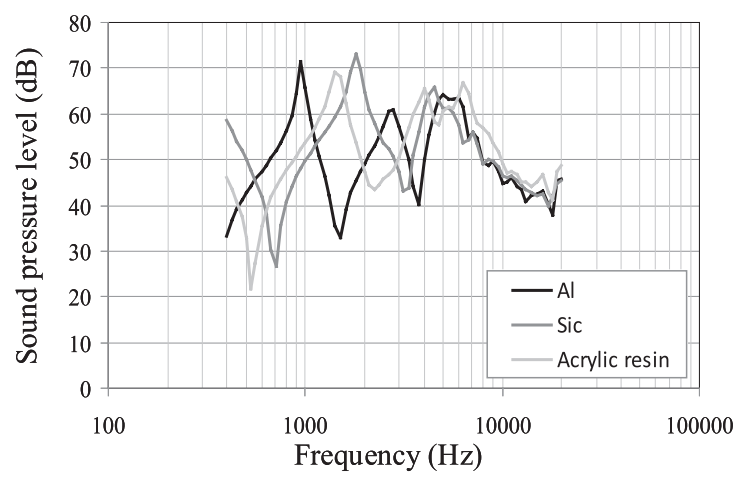

図 11 各パネル材料における音響特性解析

Fig. 11. Acoustic property analysis of each flat panel material.

材料パラメータが音響特性へ与える影響を検討した。アル ミ振動板の径 $(\phi=200 \mathrm{~mm})$ は固定とし, 同形状でパネル 材料を変化させ，材料別の音響特性を検討した。

今回の検討に用いたパネル材は炭化ケイ素 $(\mathrm{SiC})$, およ びアクリル合成樹脂を選んだ。各々の材料における構造体 の振動と直接関係のある材料デー夕を以下の表 2 に示す。 それぞれのパネル材を用いた場合, 超磁歪アクチュエータ に $1 \mathrm{~V}$ 入力し，音響特性の解析比較結果を図 11 に示す。同 眓から，材料の変化により音響特性に大きな差異が見られ ることが確認出来た。音響ピークになる周波数がアルミニ ウム材のパネルでは 3 箇所見られることに対し, $\mathrm{SiC} と ア$ クリルでは 2 次ピークと 3 次ピークの間に音圧レベルが急 激減少するような谷が見られないが，それは本稿で用いた 1/12 オクターブ分析法により，低周波では周波数の刻み幅 が狭いことに対し, $1 \mathrm{kHz}$ 以上の周波数ではオクターブが高 くなることによって周波数の急激な上昇より周波数の刻み 幅が低周波領域より比較的に荒いためであり，振動特性に 原因があるとは考え難い。しかし，音圧レベルの 1 次ピー クと 2 次ピークになる周波数は材料によって大きく異なる ことが確認できた。

材料の密度に関しては同じヤング率を持つアルミニウム とアクリルの音圧レベルのピークになる周波数が大きく異 なるが，これは材料の密度がアクリルがアルミニウムより 小さいため, アクリル材のパネルがアルミニウム材のパネ ルよりスピーカーとしてより高周波での音響特性が有利で あることがわかる。

また，アルミニウムとアクリル材よりヤング率が7倍も 高い, $\mathrm{SiC}$ 材パネルの音圧レベルピーク周波数が, アルミ
ニウムとアクリル材の音圧レベルピーク周波数とほぼ同じ 結果であることが確認された。従って，パネル材の音響特 性に大きな影響を及ぼすパラメータはパネル材料の剛性よ り密度であることがわかった。

通常, ダイナミックスピーカーの設計において, スピー カーの音響特性を良くするためには, スピーカーのハード ウェアー的な設計から, 可聴領域でに全体的な音圧レベル 向上は勿論, 可聴領域での音圧レベルのピークがなく音圧 レベルが可聴領域での周波数帯域の中で, 成るべく幅広い 帯域でフラットな特性を持つスピーカーの設計が必要であ る。超磁歪アクチュエータを用いた平面スピーカーの設計 においても同じであり, 前者はアクチュエータが振動パネ ルに与える力, つまり素子のエネルギー密度や振幅を向上 するような磁気回路の設計と, 後者は共振点の調整, つま りパネル材の振動特性を考慮し, スピーカーの主な用途に 合わせたターゲットになる周波数帯域を考慮したパネルの 最適化を行うことが必要である。

\section{7. まとめ}

本稿では, 超磁歪アクチュエータを用いた平面スピーカー の音圧レベルを予測するために, 磁界・構造・音場の連成 解析手法を提案し, 実測との比較検証を行った。

また，有限要素法を用いた周波数領域での磁界解析にお いて，バイアス磁界印加時における超磁歪素子の磁歪現象 を計算するためのシンプルでありながら精度の高い解析手 法を提案した。

本稿で述べた超磁歪アクチュエータを用いた平面スピー カーの音響特性解析手法による解析結果と測定結果は良い 一致を示し, 本稿で提案した解析手法の妥当性を検証した。 提案した連成解析手法はシンプルで，信頼性が高くかつ 計算にスピードがあることを明らかにした。

以上まで述べた超磁歪アクチュエータを用いた平面スピー カーの解析手法を用いて, 平面スピーカーの最適化を行う ことを課題とした上で, 磁界・構造・音場の複雑な物理的 な現象を解明して行くことを今後の課題とする。

(平成 22 年 2 月 25 日受付, 平成 22 年 8 月 21 日再受付)

\section{文献}

(1) Y. Furuya, T. Higuchi, and N. Imaimizu: Next-Generation Actuator Materials and Devices, CMC (2006) (in Japanese) 古屋泰文・樋口俊郎・今泉伸夫 : 未来型アクチュエータ材料・デバ イス, CMC (2006)

(2) B. Yoo, M. Hirano, and K. Hirata: "Fully Coupled Electro Magneto Mechanical Analysis Method of Magnetostrictive Actuator Using 3-D Finite Element Method", The Papers of Joint Technical Meeting on Rotating Machinery and Linear Drives, IEE Japan, RM-08-52, LD-08-47 (2008) (in Japanese)

俞 炳振 - 平野正人. 平田勝弘：「3 次元有限要素法による超磁歪ア クチュエータの連成解析手法に関する研究」, 電学回転機・リニアド ライブ合同研, RM-08-52, LD-08-47 (2008)

(3) B. Yoo, M. Hirano, and K. Hirata: "Fully Coupled Electro Magneto Mechanical Analysis Method of Magnetostrictive Actuator Using 3-D Finite Element Method", ICEM'08 XVIII International Conference On Electrical Machines, CD Rom, paper No.953 (2008) 
(4) B. Yoo, M. Hirano, and K. Hirata: "Frequency Response Analysis of Giant Magentostrictive Material Based Actuator Using Finite element Method", The Papers of Technical Meeting on Linear Drives, IEE Japan, LD-09-11 (2009) (in Japanese)

俞 炳振・平野正人 ·平田勝弘: 「有限要素法を用いた超磁歪アク チュエータの周波数応答解析」,電学リニアドライブ研究会, LD-09-11 (2009)

(5) B. Yoo and K. Hirata: "Analysis Method for Giant Magnetostrictive Material Based Actuator Using FEM", IEEJ, Vol.130-D, No.6, p.721 (2010) (in Japanese)

俞 炳振・平田勝弘：「有限要素法を用いた超磁歪アクチュエータ の解析手法」, 電気学会, Vol.130-D, No.6, p.721 (2010)

(6) http://www.tdk.co.jp/techmag/inductive/200610/index.htm

( 7 ) J. Kim and E. Jung: "Finite Element Analysis for Acoustic Characteristics of a Magnetostrictive Transducer", Smart Material Structure, pp.1273-1280 (2005)

(8) J.L. Perez-Aparicio and H. Sosa: "A continuum three-dimensional, fully coupled, dynamic, non-linear finite element formulation for magnetostrictive materials", Smart Material Structure, pp.493-502 (2004)

(9) O.C. Zienkiewicz and P. Bettess: "Fluid-structure dynamic interaction and wave force", An Introduction to Numerical Treatment Int. J. Number Methods Eng., Vol.13, pp.1-16 (1978)

网 炳 振 (学生員) 1982 年生。2009 年 3 月大阪大学工学 研究科知能機能創成工学専攻卒業。同年 6 月サム スン電子 (株) 入社，現在に至る。主として機能 性材料を用いたアクチュエータとその解析手法に 関する研究に従事。
平 田 勝 弘 (上級会員) 1958 年 4 月 10 日生。1982 年 3 月大

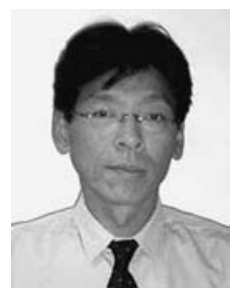
阪大学機械工学科卒業。同年 4 月松下電工 (株), 技術研究所勤務。2005 年大阪大学大学院工学研究 科知能・機能創成工学専攻・助教授を経て，2007 年同大教授，現在に至る。主として電磁アクチュ エータ，センサデバイス，有限要素法を用いた電 磁界解析に関する研究に従事。工学博士。2003 年 文部科学大臣賞 (研究功績者) 受賞。2004 年オー 厶技術賞受賞。2007 年電気学会電気学術振興賞 (進歩賞) 受賞。2009 年電気学会電気学術振興賞 (論文賞) 受賞。IEEE 会員他。

大 西 敦 郎 (学生員) 1986 年生。2009 年 3 月大阪大学工学

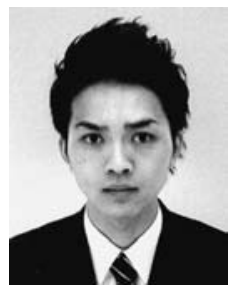
部マテリアル生産科学科目マテリアル科学コース 卒業。同年 4 月大阪大学工学研究科知能機能創成 工学専攻入学。現在に至る。主として強磁性形状 記憶合金を用いたアクチュエータとその解析手法 に関する研究に従事。 